\title{
Albert Marenčin - stretnutia bez návratov
}

\section{Viera Žemberová (Prešov)}

Neodvolatel'né udalosti l’udského života spôsobili, že sa už s Albertom Marenčinom nestretneme na slove pri žiadnej ním, či vôkol neho iniciovanej spoločenskej, kultúrnej udalosti, teda na stretávke blížencov v umení. Budeme však spomínat na vyhladávané stretnutia, ktoré sa spájajú natrvalo s jeho vlúdnostou, všestrannostou, odbornostou, rozhladenostou či spomienkami na to, čo prirodzene uplynulo, alebo nezvratne odchádza do spoločnej histórie: s ním a aj s jeho generáciou tvorcov, umelcov a súčasníkov.

Osobnost' Alberta Marenčina (26. 7. 1922 Bystré nad Topl’ou - 9. 3. 2019 Bratislava) prečnieva ponad desat'ročia dvoch storočí do európskej kultúry a umenia, do viacerých, v slovenskom kultúrnom a tvorivom kontexte, jedinečných podôb.

Všestrannost̉ Alberta Marenčina zaznamenávajú, rozčleňujú a komentujú bio-bibliografické súpisy a autorské heslá, monografické zábery s dôrazom na tvorivú jedinečnost', na jeho otvorenost’ voči podnetom a svojskému nazeraniu na celostnost̉ a výrazovú zovretost’ jeho členitej tvorby, v ktorej nechýba publicistika a rozhovory venované jemu, či vznikajúce s ním, tie sa sústred’ujú na autorovu prózu, poéziu, esejistiku, na dramatickú literatúru a literatúru faktu, na filmovú scenáristiku či na rozhlasovú tvorbu, na umelecký preklad, výtvarnú tvorbu, popri spomenutom na pozoruhodné rozpomienky Zo zápisnikov 1968-2008 (2011), na Kacirske myšlienky a nevšedné príbehy (2016), či na rozhovory s Olegom Pastierom zverejnené v Nezabúdani (2004).

Albert Marenčin spojil posledné desatročia svoj zanietený vztah ku knihe a umeniu s profilovaním vydavatel'stva Marenčin PT od jeho počiatkov, ale sústredene a s prienikmi do biografie sa vyrovnával aj s tým, čo utváralo podložie jeho osobného a profesijného života spojeného s francúzskou spoločnostou, literatúrou a umením, so surrealizmom, s oceňovanou aktivitou v československej surrealistickej skupine, s jeho členstvom v patafyzickom kolégiu v Paríži, s kontaktmi či osobnými väzbami na dianie v českej a slovenskej kultúre, na výraznú a zvlášt invenčnú prítomnost̉ v konkrétnom spoločenskom a kultúrnom čase. Nezvyčajná intenzita a šírka Marenčinovho tvorivého a všestranne rozvinutého kultúrneho záberu mu vyniesla viacero uznaní, ocenení a vyznamenaní, v ktorých sa uchová nielen rozpomienka na umelca, ale azda väčšmi to, čím zostáva natrvalo medzi nami napriek plynúcemu času.

Na počiatku nič nebráni tomu, aby sa spojilo Marenčinovo rané sprítomňovanie sa v tvorivom prostredí s ním vyslovenou takmer sentenciou, „nevedel som, čo je umenie, robil som jednoducho to, čo mi robilo dobre“. Ak dôverujeme časti „robil som jednoducho to, čo mi robilo dobre," potom niet prekážok, aby sme porozumeli tomu, čím naplnil ako umelec a talentovaný, nezvyčajne rozhl’adený človek svoj osobný a profesijný čas, čo premyslel, videl, odmietol, vykonal, komentoval a objasňoval prostredníctvom umenia sebe aj svojim 
súčasníkom. Osobne plynúci čas aj dynamika spoločenských dejov, zručnost̉ a schopnost̉ rozprávat zaujímavo a s rešpektom zotrvávala svojou podstatou pevne voči faktom aj reáliám, a tie utvárali Albertovi Marenčinovi jeho nazeranie na umenie a na individuálny, zvlášt spoločenský obsah života, čo sa uchovalo predovšetkým v esejistickej a autobiografickej spisbe Ako som sa stretol s niektorými pozoruhodnými lud’mi (1993), Nezabúdanie. Moje malé dejiny (2004), Čo nevošlo do dejín (2012), naposledy do textu Horká chut’ storočia (2018).

Spomedzi dotykov s tematickými a výrazovými makrobodmi a rozvinutými blokmi z autorských a tvorivých dejín Alberta Marenčina hodno pripomenút, že nimi zosobňuje druhý možný postoj i prístup k takej situácii, ked’ tvorivý subjekt vytlačila moc na okraj aktívneho spoločenského života, ale jeho tvorba si utvára komorné podmienky na budúcnost ako spôsob na vyjadrenie hodnoty svojho poznania a vedenia zachyteného v slove alebo v inom umeleckom artefakte. Marenčinovu literárnu tvorbu v čase samizdatu zverejňuje knižné dvojvydanie poézie s názvom Nikdy s podtitulom „Spovede a vyznania“ (knižne 1984, 1996) a Náuraty na Murán s podtitulom „Samizdaty a texty zo šuplíka“ alebo „Eseje“ (knižne 1987, 1996). Marenčinove texty vo vydaní Nikdy, Náuraty na Murán vznikli ako súbor autorskej poézie a literárnovedný výklad surrealizmu aj s opakovanými náčrtmi na jeho vývinové, javové a pojmové „definovanie“ s poučenými, osobnou skúsenostou podporenými portrétmi autorov francúzskeho a českého surrealizmu prvej polovice 20. storočia. Natrvalo ich spájajú intímne profily deviatich stúpencov Surrealistickej skupiny v Československu (Surrealistické tablo, s. 183-213) a komorný memoár, ktorým otvára Albert Marenčin biografiu svojho detstva. Vydavatelský zámer a dvojvydanie Nikdy, Návraty na Muráñ vytvoril zovretý látkový a tematický celok, čím vydavatel’ rešpektoval osobný čas, empíriu tvorcu a autentický vklad autora do dejín umenia, do vedy o umení a predovšetkým do tvorby surrealistického artefaktu. Marenčinova rozvážna, systematická, poučená, na detail problému sústredená tvorba je profesionálne vyhranená svojím nazeraním na podstatu sprostredkovanej témy, ňou sa osobnosṫ tvorcu a jeho prijímanie skutočnosti dotvára na sugestívnu a osobne vyhranenú intelektuálnu výpoved', ktorá sa dôsledne pridržiava plynúceho času a jeho obsahov. V osobnom čase Alberta Marenčina všetko, čo sa ho dotklo tak, že si ten okamih uchoval, je zanesené do jeho osobnej pamäti: napája sa na rodisko, rodičov, detstvo. Istota osobnej (intímnej) pamäti, ktorá sa v skutočnosti stala ústrednou a jedinou témou Marenčinových samizdatových textov Nikdy, Návraty na Murán si dôsledne zachováva komornost̉ na jednej strane, aby na tej druhej strane sa atmosféra výpovede napojila na jeho emócie, a tie sú číre a jednoznačné. To nimi sa vracia do regiónu a k svojej rodine, pritom sa nebráni pri sebareflexii spontánnych emócií (matka, otec), prvým záujmom (čítanie - Nadja), ani pripomenutiu si pre neho podstatných osobností (strýko, žena), ba ani dejov, či už dobrých, ale ani tých nedobrých (Paríž, Slovensko), ktoré patria do pevného podložia jeho privátnych dejín. Z odstupu prirodzenej osobnej zrelosti a v čase vnútenej straty spoločenskej identity si Albert Marenčin bez egoistického gesta a pátosu kladie otázku, kto som?, čím i takto vymedzuje náročnú trasu svojej životnej a profesijnej cesty (domov, vina, detstvo, sebapoznanie, úzkosté, láska, revolúcia...), aby v kontexte európskej literatúry objasnil svoje dozrievanie, poéziu a postupne utváral svojskú koláž zo vztahu k európskemu sur- 
realizmu od jeho genézy až po artistné výrazové vrcholy vo vývine umenia a surrealizmu ako metódy i názoru v dialógu André Breton a Vítězslav Nezval, Karel Teige a Vratislav Effenberger. Marenčinovo povedomie o sebe precizujúce jeho subjekt na poste umelca a intelektuála (vie, kam patrí) koná tak, že upozorňuje na okolnosti, ktoré ho formovali zložito a nie bez problémov. Pre rolu narátora sa rozhodol v memoárovej časti, ako sprievodca sa prejaví v literárnovedných a umenovedných pasusoch, aby osobným poznaním, videním, výberom, hodnotením prinášal v syntéze ako následok ponuky a sprostredkovanie spôsobu, výkladu, kontextu pri objasňovaní vnútorných väzieb aj ako intelektuálnu obranu či obhajobu toho, čo určovalo smerovanie slovenskej kultúrnej politiky, literárnej vedy aj umenovedy v čase a súvislostiach ním tematizovaných a znova raz, za zložitých okolností, prenechalo aj jemu pôsobisko medzi „bielymi miestami“ skutočnosti. Tenzia medzi spisovatel'om Albertom Marenčinom a ideológiou povojnovej slovenskej spoločnosti, aj eo ipso, ale predovšetkým s mechanizmom kultúrnej praxe zasiahla popri ňom aj d’alších súčasníkov, Ivana Kadlečíka, Pavla Hrúza, Milana Hamadu, Júliusa Vanoviča aj ich druhovo rozličné literárne i odborné práce a osobité autorské dielne, ktoré neznehodnotili (azda naopak) ani dlhé roky na okraji literárneho vývinu, hoci tie roky zostanú natrvalo medzi stratami ich osobných, autorských a spoločenských dejín.

Publikácia Alberta Marenčina Čo nevošlo do dejinn ${ }^{1}$ má primárne dedikačné poslanie ${ }^{2}$ autora, ale aj Doslov o nezabúdani ako tajomnej práci pamäti ${ }^{3}$, v ktorom sa zvýrazňujú v čase (pamät') neuralgické body zo života a tvorby výnimočnej osobnosti slovenskej kultúry 20. storočia. Tá sa nad’alej žánrovo úspešne odvíja od esejistiky, autobiografického podložia textovej tvorby po genologicky otvorené výzvy literatúry aj v tvorbe textov pre iné tvorivé médiá a vrcholí odkazom na „ideálnu knihu, akýsi cakumprásk dennik, intímny zápisnik, postrehy, úvahy, opisy prežitých aj vymyslených príbehov, fotografie, kresby, obrazy, doklady, opisy, listy a popri vlastných aj výpisky z kníh iných autorov [...]“4.

Autorom zamýšlané a uskutočnené vydanie publikácie Čo nevošlo do dejín možno prijat ako dôvetok k plynúcemu času, ale aj ako exkurziu do zákutí tvorby, osobností, umení, čo v prípade Alberta Marenčina treba interpretovat’ predovšetkým ako intenzívne zužitkovaný návrat, či ako podnet doplnit’ svoje záznamy o jedinečné personálne spojenia uchované v jeho pamäti s Dominikom Tatarkom, Karolom Baronom, Leopoldom Laholom, Elom Havetom, Egonom Bondym, Almou Münzovou, Ludvikom Švábom, Ivanom Mojíkom a d’alšími. Marenčin spomínaním na spoločné aktivity zvýrazňuje v jeho umeleckom živote a tvorbe nielen tvorivé osobnosti, ale neuhol vo svojich spomínaniach ani pred návratmi k činom, ktorými upozorňuje na významné udalosti z osobného a umeleckého života, ved' premýšla o zložitosti sveta umenia, a tie pripomenie ako napätie všedných i výnimočných dejov v úvodnej kapitole Moje zlaté šest'desiate. Albert Marenčin vypovedá s pokorou o tom, čo bolo a kto pri tom s ním bol, i týmto prístupom $\mathrm{k}$ minulosti

1 MARENČIN, Albert: Č́o nevošlo do dejin. Bratislava: Marenčin PT, 2012.

2 MARENČIN, Albert: Op. cit., 2012, nečíslovaná strana: „Osobitné pod'akovanie za prípravu a vydanie tejto knihy $k$ mojej devätdesiatke synom Martinovi a Albertovi a kolektivu vydavatel'stva Marenčin PT.“

3 MOJŽIŠ, Juraj: Doslov o nezabúdani ako tajomnej práci pamäti. In: MARENČIN, Albert: Op. cit., 2012, s. 261-266.

4 Prevzaté z MOJŽIŠ, Juraj: Op. cit., 2012, s. 265. 
nezaprie v sebe renesančnú osobnosṫ v umení, ale ani mravný aj existenčný pretlak prežitého v osobnom a umeleckom živote z toho, čo po mnohé roky zostávalo zamlčované, a to ho viedlo k spomienkam a návratom do času od mladosti až po aktívne žitý zrelý vek. Najskôr preto oživoval svoju pamät rozličnými žánrami v publikáciách Návraty

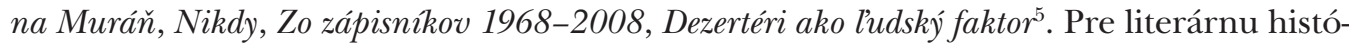
riu sa Albert Marenčin stal vzácnym a sofistikovaným pamätníkom osudov slovenského a československého surrealizmu (Vratislav Effenberger).

Ranej časti svojho literárneho života a jeho dôvetkom sa venuje v Návratoch na Murán̆ a v súbore Zo zápisnikov 1968-2008 a naznačuje, popri inom, ako ním rekonštruovaný literárny pohyb znova aktualizoval kultúrny a literárny život na konci minulého storočia a čím ho sám rozvinul do osihotených, ale jestvujúcich kultúrnych podnetov. Marenčinove „rozprávania“ o tom, ako to bolo a čo z toho vzišlo, si osvojili v „rozpomienkovej“ forme výraznú literárnu formu, spojili sa s estetickým a poznávacím zážitkom, užitočnú, nementorujúcu noetiku rokov „v škole života“, väčšmi však zo spomínaní na tých, ktorí vstupovali do školy „jeho“ občianskeho i tvorivého života. Albert Marenčin realizoval zámer, s ktorým si ich pripomína a vydáva kultivované osobné výpovede; pritom ide o precízne a na podloží faktografie o vzácne, predovšetkým autentické a potrebné svedectvo pre literárnu históriu a dejiny národnej kultúry v ich šírke a jedinečnosti.

Prítomnost' Alberta Marenčina ${ }^{6}$ obohacovala reálny kultúrny život posledných desat'ročí každým jeho autorským titulom ${ }^{7}$, spresňovala detailom a faktom slovenskú kultúrnu pamät o to, čo si sama z rozličných príčin neuchovala, alebo nedocenila v krušných dobách ako svoju povinnost': popri úsilí prežit, uchovat pre budúcnosti tie deje, ktoré podnecovala reálna spoločenská prax. Jeho kultúrna pamät má osobné rámcovanie, ale prináša zvnútra literárneho, umeleckého a kultúrneho života poznanie, bez ktorého sa len tažko možno zodpovedne prihovárat̉ súčasnosti a budúcnosti. Pre Marenčinovu prítomnost’ v kultúrnom živote nedávnej minulosti má zmysel uplatnit sentenciu, bez minulosti niet prítomnosti, ale ani budúcnosti. Takú ambíciu majú jeho Kacírke myšlienky ${ }^{8}$ zosúladené s prózou Rudolfa Slobodu Orestea a filmovým scenárom Alberta Marenčina na jej motívy s pomenovaním Filmová dráma O láske a smrti ${ }^{9}$. Obidve knižné práce sú užitočným otváraním pracovných a osobných zásuviek, ktoré sú návratom do Marenčino-

5 Albert Marenčin (1922-2019): „Nikdy bol vydaný roku 1984 a Návraty na Muráň roku 1987“. Zo zápisnikov 1968-2008. Levice: KK Bagala, 2011. MARENČIN, Albert: Op. cit., 2012, s. 266.

6 Anotované z prebalu publikácie Kacírke myšlienky (2016): Albert Marenčin (1922-2019): spisovatel', básnik, surrealista, filmár, dramaturg; vyštudoval bratislavskú filozofickú fakultu; v roku 1944 sa zúčastnil v SNP; po vojne pracoval v Národnej obrode; pokračoval v štúdiách v Paríži; od konca štyridsiatych rokov do roku 1972 pracoval v Československom štátnom filme, po prepustení z politických dôvodov nemohol publikovat; do roku 1987 pracoval v Slovenskej národnej galérii; bol členom patafyzického kolégia v Paríži a československej surrealistickej skupiny. Iné autorské heslá pridávajú k aktivitám A. Marenčina i tieto: kolážista, esejista, výtvarník, prekladatel', kritik.

7 Z prác Alberta Marenčina, ktoré vstúpili do literárnej a kultúrnej biografie slovenskej spoločnosti Nikdy a Návraty na Muráñ (1996), Nezabúdajme. Moje malé dejiny (2004), Zo zápisnikov 1968-2008 (2011), Čo nevošlo do dejín (2012).

8 MARENČIN, Albert: Kacírke myšlienky a nevšedné príbehy. Bratislava: Marenčin PT, 2016.

9 SLOBODA, Rudolf: Orestea. MARENČIN, Albert: Filmová dráma O láske a smrti. Bratislava: Marenčin PT, 2016. 
vých dávnejších rokov, do čias prežitých v štyridsiatych rokoch v Paríži, pripomenutie si Prahy a jej povesti o večnom Židovi a vyznanie sa z umeleckého vzţahu k Appolinairovi; tak pôsobí v Kacírsych myšlienkach čast̉ Rozlúčka s minulostou ${ }^{10}$. Paríž ožil v Kacírskych myšlienkach v názvoch ulíc, námestí a štvrtí vel'komesta, v pocitoch osamelosti a spomienok na domov na východnom Slovensku, ale aj ako oživená rozpomienka na tých, ktorí utvárali umeleckého ducha doby, na experimenty, aby obnovovali atmosféru umeleckej avantgardy a moderny v povojnových rokoch v meste nad Seinou (Jean-Paul Sartre, André Breton, Jeffrey Epstein, León Moussinac, Roberto Rosselini, Orson Welles, Jean Cocteau a d’alší). Albert Marenčin povedal o sebe „Nevedel som, čo je umenie, robil som jednoducho to, čo mi robilo radost", ale k ambícii umelca - v jeho povojnových parížskych rokoch - rozhlasového pracovníka, študenta filmovej akadémie, prekladatela z francúzštiny, nechýbala skúsenost', ktorej porozumel - a nielen ako cudzinec - „ked’ je človeku dobre, stači si sám, ked’ je mu smutno, žiada sa mu l’udi"11. Kacírske myšlienky prinášajú súbor odlišných textov, reagujú na politikum nedávnej prítomnosti, prelínajú sa v nich osobné a literárne motivácie zachytené $V$ nevšedných príbehoch a všedných legendách, no uzatvára ich Rozlúčka s minulostou. Nezvyčajne široké rozpätie tvorivých záujmov Alberta Marenčina si našlo dostredivé miesto vo filme ${ }^{12}$ a v tvorbe pre toto médium: „Začiatkom pät'desiatych rokov som napisal scenár o vyvraždeni a vypáleni východoslovenskej dedinky Tokajik ustupujúcimi nemeckými vojskami $[. . .]^{13}$. Scenár získal hlavnú cenu v literárnej sútaži $k$ výročiu oslobodenia [...], pôvodný scenár ostal natrvalo „vítazným“ scenárom, prerábky ostali prerábkami a moje vel'kolepé plány spomienkami“"14. Roky pôsobenia vo filmovej tvorbe pripravili Albertovi Marenčinovi pripomenutú skúsenost', ale aj d’alšiu, ktorú zachytil vo svojej rozpomienke $O$ vzniku literárneho scenára Orestea: „Napisat' literárny scenár podla Slobodovej poviedky Orestea, uverejnenej 21. apríla 1967 v literárnom týždenniku Kultúrny život, mi navrhol režisér Štefan Uher krátko potom, čo ma na Kolibe zbavili funkcie vedúceho I. tvorivej skupiny a preradili za radového dramaturga do inej skupiny. "15 Jeho rekonštrukcia osobnej pozície pracovníka Slovenskej filmovej tvorby sa neodlišuje od stoviek príbehov d’alších tvorivých pracovníkov slovenskej kultúry na prelome šesṫdesiatych a v sedemdesiatych rokoch. V tom však nespočíva ústredná príčina, prečo pripravil na vydanie dokument o spolupráci s Rudolfom Slobodom ${ }^{16}$, skôr chcel pre rovesníkov autora oživit osobnú skúsenost’ s minulostou a praxou v kultúrnom a literárnom živote v minulom storočí a pre nástupcov prináša dokument o invenčnej profesii scenáristu zachytený vo filmovej dráme $O$ láske a smrti. Tak ako scenár o tokajíckej tragédii, ani scenár inšpirovaný prózou Orestea sa nestal filmovou skutočnostou: „Po smrti všetkých tých, ktori sa na jeho príprave nejako zúčastnili - Ruda Slobodu aj Štefana Uhera, Tibora Vichtu aj Moniky Gajdošovej, neostal

10 MARENČIN, Albert: Kacírske myšlienky a nevšedné príbehy. Op. cit., s. 115-166.

11 MARENČIN, Albert: Op. cit., čast̉ Pyrenejský med, s. 164.

12 Albert Marenčin sa scenáristicky vyrovnával s literárnou predlohou inšpirovanou textami napríklad Jána Kalinčiaka a Petra Karvaša.

13 Tokajická tragédia zaujala aj básnika Pavla Horova.

14 MARENČIN, Albert: Kacírske myšlienky a nevšedné príbehy. Op. cit., časť Šibenické zvony, s. 128-129.

15 SLOBODA, Rudolf: Orestea. Albert Marenčin: Filmová dráma O láske a smrti. Op. cit., s. 7.

16 Rudolf Sloboda (1938-1995). 
už vlastne okrem mňa nikto, čo by si naň ešte dnes mohol spomenút. 28. januára 1999“17. Marenčinov profesijný príbeh nadaného, všestranne tvorivého umelca a kultúrneho činovníka obsiahol a spoločenskými zásahmi, ich dôsledkami naplnil a zaplnil poslednú autorovu kapitolu v dejinách o genéze a premenách slovenskej modernej kultúry a umenia v tých desaţročiach, ku ktorým sa treba navracat’ a do prítomnosti vrátił to, čo hodnotou, alebo pre kultúrnu pamät zostalo „v trezoroch“. Najskôr tak sa naplní úsilie aj želanie Alberta Marenčina, ktorým naposledy oslovuje nasledovníkov.

\section{Literatúra}

MOJŽIŠ, Juraj: Albert Marenčin - filmár na križovatke času. Bratislava: Slovenský filmový ústav, 2007.

prof. PhDr. Viera Žemberová, CSc.

Inštitút slovakistiky a mediálnych štúdií

Filozofická fakulta, Prešovská univerzita v Prešove

UI. 17. novembra 1, 08000 Prešov, Slovensko

viera.zemberova@ff.unipo.sk

17 SLOBODA, Rudolf: Orestea. Albert Marenčin: Filmová dráma O láske a smrti. Op. cit., s. 11. 